women at young ages, as one would expect; there was also a somewhat higher proportion aged over 70 compared with 30-69 years. There has been a tendency for the proportion of women having very large families to decrease, and this was again reflected by an increased proportion of women in the high parous group at older ages. The data were originally examined for those having three, four, or five or more children; it was particularly in those having five or more children that the proportion at the older age groups was higher.

One crucial point about this study is whether it was appropriate to assume that the relative risk of breast cancer is constant within parity subgroups over a wide age range; unfortunately this issue has not been adequately quantified. The nearest set of data most relevant to this was a study by Miller et al, ${ }^{6}$ who examined the parity for women in three provinces in Canada registered with all forms of malignant disease in 1969-71. By special inquiry parity for these women was obtained and compared with the census data. The relative risk of breast cancer in women having four or more children compared with nulliparae was similar in the age ranges $20-44,45-54$, and 55 years and over.

Applying England and Wales incidence rates to the age distribution of women by parity enabled the average age at diagnosis to be estimated; the results approximate to the findings of Woods et al. ${ }^{1}$ It was suggested that their result was a reflection of variation in the age distribution of women by parity, rather than any particular influence of parity on accelerating or slowing the date of presentation of breast cancer.

I acknowledge the financial support of the division of epidemiology from the Cancer Research Campaign, and thank my secretary Mrs Doreen Folkes; Dr Jocelyn Chamberlain for comments; and Mrs Barbara Staines for checking my calculations.

\section{References}

1 Woods KL, Smith SR, Morrison JM. Parity and breast cancer: evidence of a dual effect. $B r$ Med $\mathcal{F} 1980 ; 281: 419-21$.

${ }^{2}$ Farr W. In: Registrar General of Births, Deaths, and Marriages in England. 5th annual report. London: HMSO, 1843:38-46.

3 Office of Population Censuses and Surveys. Census 1971, England and Wales. Fertility tables. Vol 1. London: HMSO, 1979.

4 General Register Office. Census 1961, England and Wales. Fertility tables. London: HMSO, 1966

${ }^{5}$ Office of Population Censuses and Surveys. Cancer statistics: registrations for England and Wales 1975. London: HMSO, 1981.

${ }^{6}$ Miller AB, Barclay THC, Choi NW, et al. A study of cancer, parity and age at first pregnancy. $\mathcal{F}$ Chron Dis 1980;33:595-605.

(Accepted 9 fune 1981)

\title{
Interrelations of calcium-regulating hormones during normal pregnancy
}

\author{
MALCOLM WHITEHEAD, GEOFFREY LANE, OSYTH YOUNG, STUART CAMPBELL, \\ GAMINI ABEYASEKERA, CARMEL J HILLYARD, IAIN MACINTYRE, \\ KHENG GUEK PHANG, JOHN C STEVENSON
}

\begin{abstract}
Profound changes in calcium metabolism occur during pregnancy. The mother has to make available extra calcium for fetal requirements while ensuring that her plasma and bone calcium concentrations are satisfactorily maintained. In a cross-sectional study plasma concentrations of the major calcium-regulating hormones-namely, calcitonin, parathyroid hormone, 25hydroxyvitamin D (25-OHD), and 1,25-dihydroxyvitamin D $\left(1,25-(\mathrm{OH})_{2} \mathrm{D}\right)$-were measured to establish their interrelations during normal pregnancy. The major changes observed were increases in the circulating concentrations of $1,25-(\mathrm{OH})_{2} \mathrm{D}$ and calcitonin. Concentrations of parathyroid hormone and 25-OHD remained within the normal range.
\end{abstract}

\footnotetext{
Department of Obstetrics and Gynaecology, King's College Hospital Medical School, London SE5 8RX

MALCOLM WHITEHEAD, MRCOG, lecture

GEOFFREY LANE, MB, BS, research fellow

OSYTH YOUNG, SRN, SCM, research nurse

STUART CAMPBELL, FRCOG, professor

Endocrine Unit, Royal Postgraduate Medical School, Hammersmith Hospital, London W12 0HS

GAMINI ABEYASEKERA, senior technician

CARMEL J HILLYARD, BSC, PHD, senior research officer

IAIN MACINTYRE, DSC, FRCP, professor

KHENG GUEK PHANG, technician

JOHN C STEVENSON, MB, MRCP, honorary senior registrar
}

The increased concentrations of $1,25-(\mathrm{OH})_{2} \mathrm{D}$ enable the increased physiological need for calcium to be met by enhancing intestinal absorption of this element. The simultaneous rise in calcitonin opposes the bone-resorbing activities of $1,25-(\mathrm{OH})_{2} \mathrm{D}$, thereby protecting the integrity of the maternal skeleton. Maternal calcium homoeostasis is thus maintained yet the requirements of the fetus are fulfilled.

\section{Introduction}

The increased physiological requirement for calcium during pregnancy presents a major challenge to maternal calcium homoeostasis. The needs of the growing fetus have to be supplied but at the same time maternal bone and plasma calcium concentrations have to be maintained. If both these conditions are to be fulfilled changes in the secretion of calciumregulating hormones must occur.

To determine the gestational changes in the secretion of calcium-regulating hormones we measured the plasma concentrations of calcitonin, parathyroid hormone, and the vitamin $\mathrm{D}$ metabolites 25-hydroxyvitamin $\mathrm{D}$ (25-OHD) and 1,25dihydroxyvitamin $\mathrm{D}\left(1,25-(\mathrm{OH})_{2} \mathrm{D}\right)$ on four occasions during entirely normal pregnancies in a cross-sectional study. Previous studies either have been conducted only at the end of pregnancy or have been incomplete as important hormones have not been measured and details of the obstetric outcome have invariably been lacking. Thus the full interrelations of the calciumregulating hormones in normal pregnancy have not been shown. 


\section{Subjects and methods}

SUBJECTS

Patients-We studied four groups of apparently healthy white volunteers between the ages of 19 and 36 years. Each group consisted of 10 or 11 patients, and venepuncture was performed between 10 and 12 weeks, 20 and 22 weeks, 30 and 32 weeks, or 36 and 40 weeks of pregnancy. All the women had had a normal antenatal course up to this time, and the gestational age had been accurately determined by early ultrasound examination. No patient had taken any drugs apart from iron and folic acid supplements for at least three months before the sampling. All pregnancies were singleton and resulted in a fullterm delivery of a live healthy baby of appropriate weight. Venous blood was taken between 1130 and 1330 but before the midday meal; this coincided with the peak of calcitonin secretion ${ }^{1}$ but avoided adverse effects of recently absorbed fat on the assays. Most of the samples were obtained between May and July to avoid seasonal variations in vitamin $\mathrm{D}$ metabolites. Venous blood was collected into cooled heparinised tubes and the plasma immediately separated. The samples were stored at $-20^{\circ} \mathrm{C}$ until assayed.

Controls-Normal, non-pregnant female volunteers were used as separate controls for each hormone measurement. None of these women was receiving any drugs, and their age ranges were comparable with those of the pregnant patients.

\section{METHODS}

Calcitonin concentrations were measured in plasma by either direct radioimmunoassay (seven-day incubation) as previously described ${ }^{2}$ or in combination with an extraction technique. ${ }^{1}$ The sensitivity was $2 \mathrm{pg} /$ tube. Intra-assay and interassay variations were $6.4 \%$ and $8.6 \%$ respectively for the direct assay and $<10 \%$ and $<14 \%$ for the combined extraction-assay system.

Parathyroid hormone concentrations were measured in plasma by radioimmunoassay as previously described using antisera primarily directed to the $\mathrm{N}$ terminal. ${ }^{3}$ The sensitivity was $10 \mathrm{pg} /$ tube, and intraassay and inter-assay variations were $7.6 \%$ and $9.2 \%$ respectively.

25-OHD concentrations were measured in plasma by a competitive protein-binding assay as previously described. ${ }^{4}$ The sensitivity was $50 \mathrm{pg} /$ tube, and intra-assay and interassay variations were $10.1 \%$ and $13.2 \%$ respectively.

$1,25-(\mathrm{OH})_{2} \mathrm{D}$ concentrations were measured by a radioreceptor assay using an intestinal receptor preparation ${ }^{5}$ and a modified extraction and separation procedure by high-performance liquid chromatography ( $G$ Abeyasekera and I MacIntyre, unpublished data). The detection limit was $5 \mathrm{ng} / \mathrm{l}$, and intra-assay and interassay variations were $<10 \%$.

Statistical analysis-Two-tailed, unpaired Student's $t$ tests using $\log$ transformation were used for analysis of data. The $\chi^{2}$ test was used for variables with large numbers of undetectable values.

\section{Results}

Figures 1 and 2 and the table show the results. Concentrations of both $1,25-(\mathrm{OH})_{2} \mathrm{D}$ and calcitonin were appreciably increased during each stage of pregnancy (figs 1 and 2 ). In the pregnant women concentrations of parathyroid hormone remained within physiological limits but were lower than those in the controls; they were higher towards the beginning and end of pregnancy but fell between 20 and 30 weeks. Concentrations of 25-OHD decreased slightly towards the lower limit of the physiological range during the latter half of pregnancy, but this was not significant (table).

\section{Discussion}

Previous studies by our own group ${ }^{6}$ and others ${ }^{7-10}$ have shown increased concentrations of $1,25-(\mathrm{OH})_{2} \mathrm{D}$ towards the end of pregnancy. Our current findings confirm these results and also agree well with those of Kumar et al, ${ }^{11}$ who observed raised concentrations throughout pregnancy. The major action of $1,25-(\mathrm{OH})_{2} \mathrm{D}$ is to maintain plasma calcium concentrations, which is achieved by increasing the absorption of calcium from the gut and by accelerating bone resorption. Our data thus explain the enhanced intestinal absorption of calcium that is

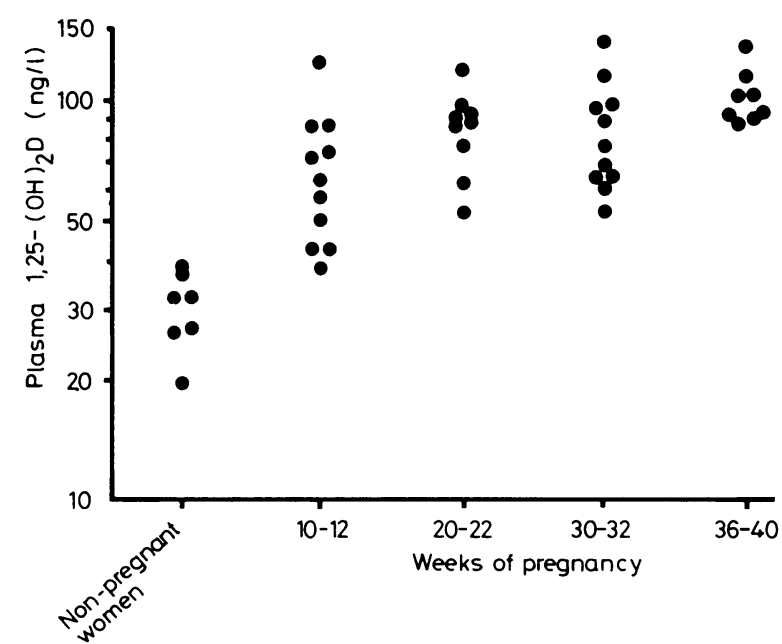

FIG 1-Plasma 1,25-(OH $)_{2} \mathrm{D}$ concentrations in controls and women during pregnancy.

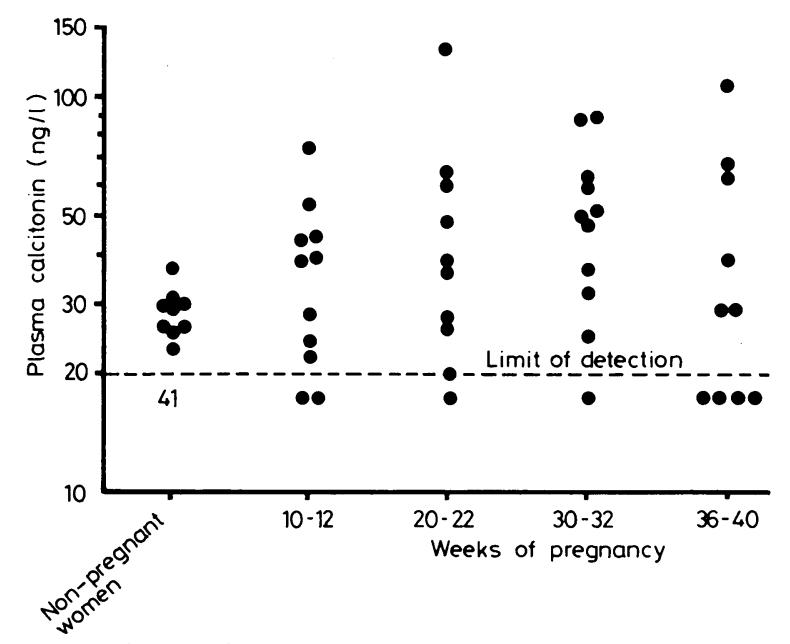

FIG 2-Plasma calcitonin concentrations in controls and women during pregnancy.

Concentrations of calcium-regulating hormones in pregnant women compared with non-pregnant controls

\begin{tabular}{|c|c|c|c|c|c|}
\hline & \multirow{2}{*}{ Controls } & \multicolumn{4}{|c|}{ Pregnant women } \\
\hline & & $\begin{array}{r}10-12 \\
\text { weeks }\end{array}$ & $\begin{array}{l}20-22 \\
\text { weeks }\end{array}$ & $\begin{array}{l}30-32 \\
\text { weeks }\end{array}$ & $\begin{array}{l}36-40 \\
\text { weeks }\end{array}$ \\
\hline $\begin{array}{l}\text { Mean concentration }(\mathrm{ng} / \mathrm{l}) \\
t \\
\mathrm{p}\end{array}$ & $29 \cdot 5^{1,2}$ & $\begin{array}{c}(\mathrm{OH})_{2} \mathrm{D} \\
63 \cdot 1 \\
4.56 \\
<0.001\end{array}$ & $\begin{array}{c}81.3 \\
8.50 \\
<0.001\end{array}$ & $\begin{array}{c}79 \cdot 4 \\
7.46 \\
<0.001\end{array}$ & $\begin{array}{r}100 \cdot 0 \\
12 \cdot 24 \\
<0 \cdot 001\end{array}$ \\
\hline \multicolumn{6}{|l|}{ No of women with } \\
\hline $\begin{array}{l}\quad<20 \mathrm{ng} / 1 \\
20-40 \mathrm{ng} / 1 \\
>40 \mathrm{ng} / 1 \\
\chi_{\mathrm{p}}^{2}(1 \mathrm{df})\end{array}$ & $\begin{array}{r}41 \\
9 \\
0\end{array}$ & $\begin{array}{c}2 \\
5 \\
4 \\
17.57 \\
<0.001\end{array}$ & $\begin{array}{c}1 \\
5 \\
4 \\
20 \cdot 74 \\
<0.001\end{array}$ & $\begin{array}{c}1 \\
3 \\
7 \\
22 \cdot 71 \\
<0.001\end{array}$ & $\begin{array}{c}4 \\
3 \\
3 \\
5 \cdot 83 \\
<0.025\end{array}$ \\
\hline \multicolumn{6}{|c|}{ Parathyroid hormone } \\
\hline $\begin{array}{l}\quad<100 \mathrm{ng} / 1 \\
\quad>100 \mathrm{ng} / \mathrm{l} \\
\chi^{2}(\mathrm{l} \text { df }) \\
\text { p }\end{array}$ & $\begin{array}{r}2 \\
20\end{array}$ & $\begin{array}{c}9 \\
2 \\
20.6 \\
<0.001\end{array}$ & $\begin{array}{c}10 \\
0 \\
25.89 \\
<0.001\end{array}$ & $\begin{array}{c}11 \\
0 \\
27.01 \\
<0.001\end{array}$ & $\begin{array}{c}8 \\
2 \\
19.47 \\
<0.001\end{array}$ \\
\hline $\begin{array}{l}\text { Mean concentration }(\mathrm{ng} / \mathrm{l}) \\
t \\
\mathrm{p}\end{array}$ & $9 \cdot 9$ & $\begin{array}{c}O H D \\
13 \cdot 2 \\
1 \cdot 31 \\
\text { NS }\end{array}$ & $\begin{array}{l}13 \cdot 5 \\
1 \cdot 10 \\
\text { NS }\end{array}$ & $\begin{array}{l}8.9 \\
0.50 \\
\text { NS }\end{array}$ & $\begin{array}{l}8.5 \\
0.78 \\
\text { NS }\end{array}$ \\
\hline
\end{tabular}


found early in pregnancy and is further increased thereafter ${ }^{12} 13$ as $1,25-(\mathrm{OH})_{2} \mathrm{D}$ concentrations rise still higher to attain maximal values towards the end of pregnancy. Plasma concentrations of 25-OHD were mainly unchanged by pregnancy.

The increase in calcitonin concentrations during pregnancy observed in this study confirms our earlier report ${ }^{2}$ and agrees with the findings of most ${ }^{10}{ }^{14-18}$ but not all other workers. ${ }^{17} 18$ This increase in secretion of calcitonin is of fundamental importance. $1,25-(\mathrm{OH})_{2} \mathrm{D}$ has most potent bone-resorbing activities, ${ }^{19}$ but these are opposed by calcitonin. The result of the interaction between these two hormones is therefore provision of calcium for the fetus from the maternal gut and not from the maternal skeleton.

Concentrations of parathyroid hormone remained rather low throughout pregnancy. They declined during the second and early part of the third trimesters, confirming the reports of Cushard $e t a^{20}$ and Bouillon and De Moor. ${ }^{21}$ Our data provide further evidence that a state of hyperparathyroidism does not occur during pregnancy. ${ }^{910} 22$ These findings are at variance with those of other workers. ${ }^{1417182023}$ Drake et al ${ }^{14}$ found a rise in parathyroid hormone concentrations after 21 weeks' gestation, but the values in their study were all within the normal range. Similarly, Pitkin et $a^{17}$ found only a slight rise in concentration and again all values were normal. Supraphysiological concentrations were found by Cushard $e t a^{20}$ and Bouillon and De Moor ${ }^{21}$ but only at the end of pregnancy; recent studies have not confirmed this finding. ${ }^{910} 22$ Thus despite many claims that a state of hyperparathyroidism exists during pregnancy only two studies ${ }^{1823}$ have found raised concentrations of parathyroid hormone throughout pregnancy; Reitz et $a l^{23}$ used C-terminal antisera, and the characteristics of the parathyroid hormoné antisera of Conforti et al $^{18}$ were not specified. Our antisera were directed to the biologically active $\mathbf{N}$ terminal of the hormone. While increased secretion of the hormone was previously thought necessary to stimulate production of $1,25-(\mathrm{OH})_{2} \mathrm{D}$ during pregnancy, it is now known that other hormones that are increased during pregnancy, such as prolactin and human placental lactogen, can directly effect increased production of $1,25-(\mathrm{OH})_{2} \mathrm{D}$ in primary chick kidney cell cultures, ${ }^{24}$ and it is reasonable to suggest that similar mechanisms may occur in man. Indeed, the concept of gestational hyperparathyroidism is incompatible with other well-documented observations. A major action of parathyroid hormone is to promote renal retention of calcium, yet hypercalciuria is well recognised during pregnancy. Additionally, increased activity of parathyroid hormone in conjunction with raised concentrations of $1,25-(\mathrm{OH})_{2} \mathrm{D}$ would enhance bone resorption and perhaps result in bone loss, but this does not occur during normal pregnancy. ${ }^{25}$

Circulating calcitonin concentrations are extremely low in non-pregnant women, ${ }^{28}$ and thus it is tempting to speculate that failure to increase secretion of calcitonin during pregnancy would permit unopposed bone resorption and might be important in the pathogenesis of the rare osteoporosis occurring after pregnancy. In addition, increased production of $1,25-(\mathrm{OH})_{2} \mathrm{D}$ demands adequate concentrations of $25-\mathrm{OHD}$, and thus women who are already vitamin $\mathrm{D}$ deficient might rapidly develop osteomalacia during pregnancy. Further studies are needed to confirm or refute these suggestions.

We believe that our data on the interrelations of the calciumregulating hormones explain how the major stress of pregnancy on calcium and bone metabolism is successfully countered and suggest how certain pathological disorders of bone might occasionally arise.

We are most grateful for the support of the Medical Research Council and Laboratoires Besins Iscovesco for these studies, and for the advice of Professor Michael Healey on the data presentation and statistical analysis.

MRC reagents $70 / 50,76 / 907,71 / 324$, and $76 / 517$ were kindly supplied by the National Institute for Biological Standards and Control, Hampstead, and synthetic human calcitonin by Ciba-Geigy.

\section{References}

${ }^{1}$ Hillyard CJ, Cooke TJC, Coombes RC, Evans IMA, MacIntyre I. Norma plasma calcitonin: circadian variation and response to stimuli. Clin Endocrinol 1977;6:291-8.

2 Stevenson JC, Hillyard CJ, MacIntyre I, Cooper H, Whitehead MI. A physiological role for calcitonin: protection of the maternal skeleton. Lancet 1979 ;ii:769-70.

3 Brodie MJ, Boobis AR, Dollery CT, et al. Rifampicin and vitamin D metabolites. Clin Pharmacol Ther 1980;27:810-4.

4 Wilmana PF, Brodie MJ, Mucklow JC, et al. Reduction of circulating 25hydroxyvitamin D by antipyrine. Br f Clin Pharmacol 1979;8:523-8.

5 Eisman JA, Hamstra AJ, Kream BE, DeLuca HF. A sensitive, precise and convenient method for determination of 1,25 dihydroxyvitamin $\mathrm{D}$ in human plasma. Arch Biochem Biophys 1976:176:235-43.

6 Brown DJ, Spanos E, MacIntyre I. Role of pituitary hormones in regulating renal vitamin D metabolism in man. $\mathrm{Br} M e d f 1980 ; 280: 277-8$.

${ }^{7}$ Pike JW, Toverud S, Boass A, McCain T, Haussler MR. Circulating $1 \propto 25-(\mathrm{OH})_{2} \mathrm{D}$ during physiological states of calcium stress. In : Norman AW, Schaefer K, Coburn JW, et al, eds. Vitamin D: biochemical, chemical and clinical aspects related to calcium metabolism. Berlin: de Gruyter, 1977:187-9.

${ }^{8}$ Lund B, Selnes A. Plasma 1,25-dihydroxyvitamin D levels in pregnancy and lactation. Acta Endocrinol 1979;92:330-5.

- Steichen JJ, Tsang RC, Gratton TL, Hamstra A, DeLuca HF. Vitamin D homeostasis in the perinatal period. N Englf Med 1980;302:315-9.

10 Wieland P, Fischer JA, Trechsel U, et al. Perinatal parathyroid hormone, vitamin D metabolites, and calcitonin in man. Am $\mathcal{F}$ Physiol $1980 ; 239$ : E385-90.

${ }^{11}$ Kumar R, Cohen WR, Silva P, Epstein PH. Elevated 1,25 dihydroxyvitamin D plasma levels in normal human pregnancy. $\mathcal{F}$ Clin Invest 1979; $63: 342-4$.

12 Shenolikar IS. Absorption of dietary calcium in pregnancy. Am $\mathcal{F}$ Clin Nutr $1970 ; 23: 63-7$.

${ }^{13}$ Heaney RP, Skillman TG. Calcium metabolism in normal human pregnancy. F Clin Endocrinol Metab 1971 ;33:661-70.

14 Drake TS, Kaplan RA, Lewis TA. The physiologic hyperparathyroidism of pregnancy. Is it primary or secondary? Obstet Gynecol 1979;53: 746-9.

15 Samaan NA, Anderson GD, Adam-Mayne ME. Immunoreactive calcitonin in the mother, neonate, child and adult. Am $\mathcal{f}$ Obstet Gynecol $1975 ; 121: 622-5$.

${ }^{16}$ Kovaric J, Woloszczuk W, Linkesch W, Pavelka R. Calcitonin in pregnancy. Lancet 1980;i :199-200.

17 Pitkin RM, Reynolds WA, Williams GA, Hargis GK. Calcium metabolism in normal pregnancy: a longitudinal study. Am F Obstet Gynecol 1979; 133:781-90.

18 Conforti A, Biale Y, Levi M, Shany S, Shainkin-Kestenbaum R, Berlyne GM. Changes in serum calcitonin, parathyroid hormone and 25-hydroxycholecalciferol levels in pregnancy and labour. Mineral and Electrolyte Metabolism 1980;3:323-8.

19 Raisz LG, Canalis EM, Dietrich JW, Kream BE, Gworek SC. Hormonal regulation of bone formation. Recent Prog Horm Res 1978;34:335-56.

${ }^{20}$ Cushard WG, Creditor MA, Canterbury JM, Reiss E. Physiologic hyperparathyroidism in pregnancy. $\mathcal{F}$ Clin Endocrinol Metab 1972;34: 767-71.

21 Bouillon R, De Moor P. Pathophysiological data obtained with a radioimmunoassay for human parathyroid hormone. Ann Endocrinol (Paris) $1973 ; 34: 657-67$.

22 Hillman LS, Slatopolsky E, Haddad JG. Perinatal vitamin D metabolism. IV. Maternal and cord serum 24,25 dihydroxyvitamin D concentrations. f Clin Endocrinol Metab 1978;47:1073-7.

${ }^{23}$ Reitz RE, Daane TA, Woods JR, Weinstein RL. Calcium, magnesium, phosphorus and parathyroid hormone inter-relationships in pregnancy and newborn infants. Obstet Gynecol 1977,50:701-5.

24 Spanos E, Brown DJ, Stevenson JC, MacIntyre I. Stimulation of 1,25dihydroxycholecalciferol production by prolactin and related peptides in intact renal cell preparations in vitro. Biochim Biophys Acta 1981 ;672: 7-15.

25 Nilsson BE. Parity and osteoporosis. Surg Gynecol Obstet 1969;129:27-8.

${ }^{26}$ Hillyard CJ, Stevenson JC, MacIntyre I. Relative deficiency of plasmacalcitonin in normal women. Lancet $1978 ; \mathrm{i}: 961-2$.

(Accepted 8 May 1981)

\section{OF NERVOUS DISEASES.}

FEw things tend more to ftrengthen the nervous fyftem than cold bathing. This practice, if duly perfifted in, will produce very extraordinary effeets; but when the liver or other vifcera are obftructed, or otherwife unfound, the cold bath is improper. It is therefore to be ufed with very great caution. The moft proper feafons for it are fummer and autumn. It will be fufficient, efpecially for perfons of a fpare habit, to go into the cold bath three or four times a-week. If the patient be weakened by it, or feels chilly for a long time after coming out, it is improper.

(Buchan's Domestic Medicine, 1786.) 